\title{
Penggunaan H-Zeolit dan Tawas dalam Pemurnian Crude Glycerol dengan Proses Adsorpsi dan Koagulasi
}

\author{
Nur Hijjah B Fadhillah, Isalmi Aziz, Hendrawati
}

Program Studi Kimia FST UIN Syarif Hidayatullah Jakarta

J1. Ir. H. Juanda No.95 Ciputat Jakarta 15412

Email: isalmikimia@uinjkt.ac.id; bayanifadhillah16@gmail.com

Received: Maret 2017; Revised: April 2017; Accepted: Mei 2017; Available Online: Mei 2017

\begin{abstract}
Abstrak
Pembuatan biodiesel dari minyak goreng bekas menghasilkan produk samping berupa crude glycerol dengan kemurnian yang rendah. Crude glycerol ini mengandung senyawa pengotor seperti asam lemak bebas, alkohol, sabun, katalis dan air. Adsorpsi senyawa pengotor dapat dilakukan dengan zeolit alam, tetapi kualitas yang dihasilkan masih kurang baik. Untuk meningkatkan kualitasnya maka pada penelitian ini ditambahkan tawas (koagulasi) pada proses adsorpsi sehingga senyawa pengotor yang berukuran koloid bisa dipisahkan dari gliserol. Penelitian ini bertujuan untuk menentukan kondisi optimum proses adsorpsi dan koagulasi senyawa pengotor dalam crude glycerol menggunakan h-zeolit dan tawas serta menentukan kualitas gliserol yang dihasilkan. Crude glycerol terlebih dahulu diasamkan menggunakan asam fosfat $85 \%$ (pure analysis) hingga mencapai $\mathrm{pH}$ \pm 2.5 . Kadar gliserol yang diperoleh dari hasil pengasaman adalah $72.797 \%$. Proses selanjutnya yaitu adsorpsi menggunakan H-zeolit dengan kadar gliserol yang diperoleh sebesar 77.079\%. Proses terakhir yang dilakukan adalah adsorpsi dan koagulasi menggunakan zeolit alam yang sudah diaktivasi dan tawas. Kadar gliserol tertinggi sebesar $93.803 \%$ diperoleh pada kondisi adsorpsi-koagulasi pada waktu 75 menit; konsentrasi tawas 80 ppm; dan suhu $60{ }^{\circ} \mathrm{C}$. Gliserol yang diperoleh dari proses adsorpsi dan koagulasi menggunakan $\mathrm{H}$-zeolit dan tawas memenuhi syarat mutu SNI 06-1564-1995 dengan kadar air 3.512\%; kadar abu 2.438\%; kadar MONG $0.247 \%$; tidak mengandung gula; massa jenis sebesar $1.259 \mathrm{~g} / \mathrm{mL}$; kadar logam kalium $0.2356 \%$ dan aluminium $0.0410 \%$; dan warna yang lebih jernih
\end{abstract}

Kata Kunci : Adsorpsi, crude glycerol, koagulasi, tawas, H-zeolit.

\begin{abstract}
Production of biodiesel from used cooking oil byproducts such as crude glycerol with low purity. The crude glycerol containing compounds impurities such as free fatty acids, alcohol, soap, catalyst and water. Compound adsorption of impurities can be done with the H-zeolite as adsorbent, but the resulting quality is still not good. To improve its quality, this research was added alum (coagulation) process so that the adsorption of colloidalsized compound impurities which can be separated from the glycerol. The purpose of this research is determine optimal condition of adsorption and coagulation impurity compounds of crude glycerol by using $\mathrm{H}$ zeolite and alum and also determine quality of glycerol was obtained. First, crude glycerol acidified by phosphoric acid $85 \%$ (pure analysis) until desired $\mathrm{pH} \pm 2.5$. It was obtained purity of glycerol $72.797 \%$. The next process is adsorption with activated H-zeolite and it obtained purity of glycerol $77.079 \%$. The last process in this research is adsorption and coagulation by using H-zeolite and alum. The highest purity glycerol $93.803 \%$ was obtained from condition of adsorption and coagulation for 75 minutes; alum's concentration 80 ppm; and temperature $60{ }^{\circ} \mathrm{C}$. The glycerol discharged from adsorption and coagulation process by using H-zeolite and alum is qualify Indonesia National Standard number 06-1564-1995 with $3.512 \%$ water content; $2.438 \%$ ash content; $0.247 \%$ MONG content; has no sugar; $1.259 \mathrm{~g} / \mathrm{mL}$ density of glycerol; $0.2356 \%$ potassium content and $0.0410 \%$ aluminium content; and brighter color.
\end{abstract}

Keywords: Adsorption, crude glycerol, coagulation, alum, H-zeolite.

DOI: http://dx.doi.org/10.15408/jkv.v0i0.5143. 


\section{PENDAHULUAN}

Crude glycerol merupakan produk samping pembuatan biodiesel yang dihasilkan sekitar $10-20 \%$ v/v. Produk ini masih banyak mengandung senyawa pengotor seperti metanol, sabun, katalis, asam lemak, air dan lain-lain (Kovaks, 2011). Jika produk ini dimurnikan maka akan menambah pendapatan bagi industri biodiesel. Pemurnian crude glycerol telah dilakukan beberapa peneliti, diantaranya Aziz et al., (2010) menggunakan karbon aktif sebanyak $2.5 \mathrm{~g}$ dengan waktu adsorpsi selama 24 jam; Manosak et al., (2010) melakukan pemurnian crude glycerol dengan menggunakan asam fosfat $\left(\mathrm{H}_{3} \mathrm{PO}_{4}\right)$, ekstraksi gliserol menggunakan pelarut polar, dan adsorpsi dengan karbon aktif komersial. Hasil analisis kualitas gliserol yang diperoleh yaitu kadar gliserol 96.2\%; kadar abu 2.08\%; kadar MONG (Matter Organic Non Glycerol) $1.50 \%$; dan gliserol yang dihasilkan tidak berwarna atau bening.

Pemurnian crude glycerol dilakukan pula oleh Aziz et al., (2014) menggunakan metode pengasaman dan adsorpsi menggunakan zeolit alam Lampung. Kondisi optimum adsorpsi zeolit pada pemurnian crude glycerol didapatkan pada waktu 75 menit, konsentrasi zeolit $12 \%$ dari massa sampel, suhu adsorpsi $60{ }^{\circ} \mathrm{C}$, dan ukuran diameter zeolit $0.2 \mathrm{~mm}$ dengan kualitas gliserol yang diperoleh setelah proses adsorpsi pada kondisi optimum memenuhi syarat mutu SNI 06-15641995, dengan kadar air 7.38\%; kadar abu 3\%; tidak mengandung gula; dan kadar gliserol sebesar $88.91 \%$. Namun, hasil penelitian ini masih terdapat kekurangan, yaitu gliserol yang dihasilkan masih berwarna coklat gelap sehingga perlu proses pemurnian lebih lanjut.

Pada penelitian ini digunakan proses adsorpsi dan koagulasi untuk meningkatkan kualitas gliserol dan warna yang dihasilkan. Proses adsorpsi dan koagulasi dilakukan dalam 1 (satu) kali proses, dimana adsorben yang digunakan adalah H-zeolit dan koagulannya adalah tawas. Pemilihan $\mathrm{H}$ zeolit sebagai adsorben karena kemampuannya unttuk menyerap senyawa pengotor dalam crude glycerol cukup baik, dimana kadar gliserol yang dihasilkan mencapai $88.91 \%$ (Aziz et al., 2014). Diharapkan dengan ditambahkan proses koagulasi dapat mengendapkan partikelpartikel yang berukuran kecil (mikroflok) sehingga membentuk partikel-partikel berukuran besar (makroflok) dan mudah untuk dipisahkan. Sebelum proses optimasi adsorpsi dan koagulasi dengan variasi konsentrasi tawas, suhu, dan waktu adsorpsi-koagulasi, dilakukan tahap pengasaman menggunakan asam fosfat $\left(\mathrm{H}_{3} \mathrm{PO}_{4}\right)$ 85\% hingga mencapai $\mathrm{pH}$ 2.5. Menurut Manosak et al., (2010), pengasaman crude glycerol hingga $\mathrm{pH} 2.5$ menggunakan $\mathrm{H}_{3} \mathrm{PO}_{4} 85 \%$ dapat menarik ion kalium yang tersisa dari penggunaan katalis $\mathrm{KOH}$ pada tahap pembuatan crude glycerol. Selanjutnya, gliserol yang dihasilkan diuji kualitasnya berdasarkan syarat mutu gliserol menurut SNI 06-1564-1995, meliputi kadar gliserol, kadar air, kadar abu, kadar MONG, kadar gula, massa jenis, dan penurunan intensitas warna gliserol yang ditentukan menggunakan spektrofotometer UV-Vis.

Selain dari parameter tersebut, dilakukan juga ananalisis kadar logam kalium (K) dan aluminium (Al) menggunakan spektrofotometer serapan atom (SSA). Logam $\mathrm{K}$ dianalisis karena pada pembuatan crude glycerol digunakan katalis $\mathrm{KOH}$. Sedangkan pengujian Al dilakukan karena pada proses adsorpsi dan koagulasi senyawa pengotor dalam crude glycerol menggunakan tawas yang mengandung logam Al. Diharapkan kedua logam ini dapat mengendap bersama senyawa pengotor lainnya dengan adanya koagulan berupa tawas sehingga tidak terdapat dalam produk akhir gliserol.

Selain itu dilakukan pula analisis terhadap pengujian penurunan intensitas warna gliserol menggunakan spektrofotometer UVVis. Penurunan intensitas warna dilakukan untuk mengetahui seberapa besar perubahan warna yang terjadi pada gliserol yang dihasilkan berdasarkan nilai absorbansi yang diperoleh.

\section{METODE PENELITIAN}

\section{Alat dan Bahan}

Alat yang digunakan pada penelitian ini adalah spektrofotometer serapan atom (SSA) (perkin elmer), Fourier Transform Infrared Spectroscopy (FTIR) Shimadzu IRPretige-21, Spektrofotometer UV-Vis Perkin Elmer Lamda 25 dan peralatan gelas lainnya. Bahan yang digunakan adalah minyak goreng bekas yang berasal dari Rumah makan Hoesen ciputat, $\mathrm{H}_{3} \mathrm{PO}_{4}$ pa (merck), etilen glikol pa 
(merck), $\mathrm{KOH}$ pa (merck) dan $\mathrm{H}_{2} \mathrm{SO}_{4}$ pa (merck).

Pembuatan Crude Glycerol (Aziz et al., 2010) $\mathrm{KOH}$ sebanyak $1.8 \mathrm{~g}$ dilarutkan dalam $50 \mathrm{~mL}$ metanol. Kemudian minyak goreng bekas dipanaskan sebanyak $200 \mathrm{~mL}$ sampai suhu $60{ }^{\circ} \mathrm{C}$, setelah itu ditambahkan larutan metanol-KOH dan diaduk menggunakan magnetic stirrer diatas hot plate. Diatur laju pengadukannya pada $500 \mathrm{rpm}$ kemudian dibiarkan selama 60 menit dan dijaga suhunya tetap konstan. Larutan yang dihasilkan dimasukkan ke dalam corong pisah, kemudian dibiarkan selama 24 jam sampai terjadi pemisahan yang sempurna. Lapisan atas merupakan lapisan biodiesel dan lapisan bawah adalah crude glycerol.

\section{Proses Pengasaman Crude Glycerol (Manosak et al., 2010) \\ Crude glycerol sebanyak $300 \mathrm{~g}$} ditambahkan dengan larutan $\mathrm{H}_{3} \mathrm{PO}_{4} \quad 85 \%$ hingga mencapai $\mathrm{pH}$ larutan \pm 2.5 . Setelah itu didiamkan selama \pm 24 jam sampai larutan membentuk 3 fasa. Lapisan paling atas merupakan asam lemak bebas, lapisan tengah adalah gliserol, dan lapisan paling bawah adalah garam anorganik. Setelah terjadi pemisahan, filtrat (crude glycerol) dipisahkan dari endapan garam dengan cara penyaringan menggunakan pompa vakum.

\section{Analisis Kualitas Gliserol}

Crude glycerol yang telah diasamkan dan dipisahkan, kemudian dilakukan analisis terhadap kualitas gliserol yang dihasilkan. Analisis gliserol yang dihasilkan meliputi kadar gliserol, massa jenis, kadar air , kadar abu, kadar gula dan kadar logam kalium (K) dan aluminium (Al).

\section{Penentuan Kadar Gliserol (SNI 06-1564- 1995)}

Crude glycerol sebanyak $0.1 \mathrm{~g}$ dilarutkan dalam $10 \mathrm{~mL}$ aquadest lalu ditambah 1 tetes indikator biru bromtimol. Larutan kemudian diasamkan dengan $\mathrm{H}_{2} \mathrm{SO}_{4}$ $0.2 \mathrm{~N}$ sampai terbentuk warna kuning kehijauan. Larutan dinetralkan dengan $\mathrm{NaOH}$ $0.05 \mathrm{~N}$ secara hati-hati sampai terbentuk warna biru. Setelah itu, larutan tersebut ditambah $\mathrm{NaIO}_{4}$ sebanyak $10 \mathrm{~mL}$ lalu diaduk secara perlahan. Larutan selanjutnya ditutup dan didiamkan dalam ruangan gelap pada suhu kamar selama 30 menit. Larutan kemudian ditambah etilena glikol sebanyak 2 $\mathrm{mL}$ lalu ditutup dan didiamkan dalam ruangan gelap pada suhu kamar selama 20 menit. Larutan diencerkan dengan $60 \mathrm{~mL}$ aquadest kemudian ditambah 3 tetes indikator bromtimol biru. Larutan hasil campuran tersebut ditirasi perlahan-lahan dengan $\mathrm{NaOH}$ $0.5 \mathrm{~N}$ sampai terbentuk warna biru. Proses tersebut juga dilakukan untuk blanko atau penambahan reagen tanpa sampel. Kadar gliserol dihitung dengan rumus dalam persamaan (1) sebagai berikut :

$$
\text { KG }(\%)=\frac{\left(T_{1}-T_{2}\right) \times N \times 9,209}{W}
$$

Keterangan :

$\mathrm{KG}=$ Kadar Gliserol $(\%)$

$\mathrm{T}_{1}=$ Volume $\mathrm{NaOH}$ untuk titrasi contoh $(\mathrm{mL})$

$\mathrm{T}_{2}=$ Volume $\mathrm{NaOH}$ untuk titrasi blanko $(\mathrm{mL})$

$\mathrm{N}=$ Normalitas $\mathrm{NaOH}(\mathrm{N})$

$\mathrm{W}=$ Bobot contoh $(\mathrm{g})$

$9.209=$ Faktor gliserol

\section{Kadar Air (AOAC, 195)}

Sampel sejumlah $5 \mathrm{~g}$ ditimbang dan dimasukkan dalam cawan yang telah dikeringkan dan diketahui bobotnya. Kemudian sampel dan cawan dikeringkan dalam oven bersuhu $105{ }^{\circ} \mathrm{C}$ selama 3 jam. Cawan didinginkan dan ditimbang, kemudian dikeringkan kembali sampai diperoleh bobot tetap. Kadar air sampel dapat dihitung dengan menggunakan persamaan (2) sebagai berikut.

$$
\mathrm{KA}=\frac{b-(c-a)}{b} \times 100 \%
$$

Keterangan :

$\mathrm{KA}=$ Kadar Air (\%)

$\mathrm{a}=$ Bobot cawan (gram)

$\mathrm{b}=$ Bobot sampel (gram)

$\mathrm{c}=$ Bobot cawan + sampel (setelah pengeringan)

\section{Massa Jenis}

Piknometer dibersihkan dengan $\mathrm{HCl}$, lalu dibilas sebanyak 3 kali dengan aquadest, sekali dengan alkohol dan kemudian dikeringkan di dalam oven selama 5 menit. Setelah itu dimasukkan ke dalam desikator selama 10 menit, lalu piknometer ditimbang hingga diperoleh massa tetap (W1). Piknometer diisi dengan larutan crude glycerol, bagian luarnya dilap hingga kering 
dan ditimbang hingga diperoleh massa yang tetap (W2). Perhitungan massa jenis crude glycerol ditunjukkan dalam persamaan (3).

$$
\mathbf{d}=\frac{\left(\mathbf{W}_{2}-\mathbf{W}_{1}\right)}{\mathbf{V}}(\mathbf{3})
$$

Keterangan:

$\mathrm{d}=$ massa jenis $(\mathrm{gr} / \mathrm{mL})$

$\mathrm{W}_{1}=$ Massa piknometer kosong $(\mathrm{g})$

$\mathrm{W}_{2}=$ Massa piknometer + crude glycerol $(\mathrm{g})$

$\mathrm{V}=$ Volume suatu larutan dalam piknometer $(\mathrm{mL})$

\section{Kadar Abu (AOAC 1995)}

Sampel sebanyak $5 \mathrm{~g}$ ditimbang dan dimasukkan ke dalam cawan porselen yang telah dikeringkan dan diketahui bobotnya. Kemudian cawan dan sampel tersebut dibakar dengan pemanas listrik dalam ruang asap, sampai sampel tidak berasap dan diabukan pada tanur pengabuan pada suhu $550{ }^{\circ} \mathrm{C}$ sampai dihasilkan abu yang berwarna abu-abu terang atau bobotnya telah konstan. Selanjutnya kembali didinginkan dalam desikator dan ditimbang segera setelah mencapai suhu ruang. Cara perhitungan kadar abu total ditunjukkan pada persamaan (4) berikut ini :

$$
\operatorname{KAbu}(\%)=\frac{W_{1}}{W_{2}} \times 100(4)
$$

Keterangan:

$$
\begin{array}{ll}
\text { KAbu } & =\text { Kadar abu }(\%) \\
\mathrm{W}_{1} & =\text { Massa Abu }(\mathrm{g}) \\
\mathrm{W}_{2} & =\text { Massa sampel }(\mathrm{g})
\end{array}
$$

\section{Kadar Gula (SNI 06-1564-1995)}

Pereaksi yang digunakan adalah pereaksi Maillard yang dibuat dengan cara sebanyak 4 g urea $\left(\mathrm{CO}\left(\mathrm{NH}_{2}\right) 2\right)$ dan 0.2 gram $\mathrm{SnCl}_{2} \cdot 2 \mathrm{H}_{2} \mathrm{O}$ dipanaskan dengan $10 \mathrm{~mL}$ $\mathrm{H}_{2} \mathrm{SO}_{4} 40 \%$. Gliserol sebanyak 4 tetes dimasukkan ke dalam tabung pereaksi. Tambahkan $1 \mathrm{~mL}$ pereaksi Maillard; $1 \mathrm{~mL}$ air suling, lalu diaduk. Panaskan tabung di dalam penangas air selama 15 menit dengan suhu 60 ${ }^{\circ} \mathrm{C}$. Warna coklat yang timbul menunjukkan adanya gula dalam gliserol.

\section{Aktivasi Zeolit Alam Lampung (Las, 1989)}

Zeolit alam Lampung jenis klinoptilolit dihaluskan lalu disaring atau diayak dengan ukuran 60 mesh atau $0,2 \mathrm{~mm}$. Selanjutnya direndam dalam aquades sambil diaduk selama 3 hari (tiap hari selama 8 jam) pada temperatur kamar. Kemudian disaring, endapan yang bersih dikeringkan dalam oven pada temperatur $120^{\circ} \mathrm{C}$ selama 2 jam. Selanjutnya zeolit direndam ke dalam larutan $\mathrm{NH}_{4} \mathrm{Cl} 1 \mathrm{M}$ selama 24 jam pada temperatur kamar. Kemudian zeolit disaring, dicuci dengan aquades dan diuji secara

kualitatif kandungan ion kloridanya $\left(\mathrm{Cl}^{-}\right)$ menggunakan larutan perak nitrat $\left(\mathrm{AgNO}_{3}\right)$ hingga tidak terbentuknya endapan kembali. Kemudian zeolit dikeringkan dalam oven pada temperatur $120^{\circ} \mathrm{C}$. Setelah dingin, zeolit diletakkan dalam cawan porselen dan di letakkan dalam furnace pada temperatur 450 ${ }^{\circ} \mathrm{C}$ selama 24 jam. Selanjutnya didinginkan dan diperoleh zeolit aktif yaitu $\mathrm{H}$-zeolit.

\section{Proses Adsorpsi dengan H-zeolit (Aziz et al., 2014)}

Sebanyak 50 g crude glycerol hasil perlakuan asam ditimbang kemudian ditambahkan $\mathrm{H}$-zeolit dengan ukuran 0,2 $\mathrm{mm}$ yang telah diaktivasi sebanyak $6 \mathrm{~g}$ (12\% dari berat crude glycerol). Campuran diaduk dengan menggunakan magnetic stirrer selama 75 menit pada suhu adsorpsi $60^{\circ} \mathrm{C}$, kemudian didiamkan selama 24 jam. Selanjutnya filtrat disaring dan dianalisis intensitas warna yang terbentuk dan kualitas gliserolnya. Prosedur analisis kualitas gliserol sama dengan prosedur pada analisis kualitas gliserol sebelumnya, yaitu meliputi kadar gliserol, kadar air, massa jenis, kadar abu, kadar gula, kadar logam kalium dan aluminium.

\section{Optimasi Proses Adsorpsi dan Koagulasi dengan H-Zeolit dan Tawas}

Sebanyak 10 g crude glycerol hasil pengasaman, ditambahkan dengan $\mathrm{H}$-zeolit sebanyak $12 \%$ dari massa crude glycerol dan tawas dengan variasi konsentrasi diantaranya $60 ; 80 ; 100$; dan 120 ppm, variasi waktu yaitu $30 ; 60 ; 75$; dan 90 menit, serta variasi suhu 30; 45; 60; dan $75{ }^{\circ} \mathrm{C}$. Setiap sampel hasil optimasi diuji kadar gliserol dan intensitas warna yang terbentuk. Sampel dengan kondisi optimum didiamkan selama 24 jam lalu disaring. Filtratnya disaring dan dianalisis kualitas gliserolnya.

\section{Uji Intensitas Warna dengan Spektrofotometer UV-VIS}

Sampel diukur nilai absorbansinya pada panjang gelombang maksimum. Setelah 
diketahui nilai absorbansi, kemudian ditentukan penurunan intensitas warnanya (PIW) dengan menggunakan persamaan (5) :

$$
\% \mathrm{PIW}=\frac{\text { Abs. blanko-Abs. sampel }}{\text { Abs. blanko }} x 100 \%(5)
$$

\section{HASIL DAN PEMBAHASAN}

\section{Pengaruh Variasi Konsentrasi Tawas}

Adsorpsi-koagulasi dilakukan dengan variabel tetap suhu $60{ }^{\circ} \mathrm{C}$, waktu 75 menit, konsentrasi H-zeolit $12 \%$ dari massa crude glycerol. Pemilihan kondisi ini berdasarkan kondisi optimum yang didapatkan oleh Aziz et al., (2014) pada pemurnian crude glycerol menggunakan zeolit. Ukuran tawas dan $\mathrm{H}$ zeolit yang digunakan adalah $0.2 \mathrm{~mm}$. Analisis kadar gliserol hasil adsorpsi dan koagulasi dengan variasi konsentrasi tawas ditunjukkan pada tabel 1 .

Tabel 1. Kadar gliserol pada variasi konsentrasi tawas

\begin{tabular}{lll}
\hline $\begin{array}{l}\text { Konsentrasi } \\
\text { Tawas (ppm) }\end{array}$ & $\begin{array}{l}\text { Kadar } \\
\text { Gliserol (\%) }\end{array}$ & $\begin{array}{l}\text { Penurunan } \\
\text { Intensitas } \\
\text { Warna (\%) }\end{array}$ \\
\hline 60 & $83.14 \pm 0.06$ & 74.48 \\
80 & $93.80 \pm 0.03$ & 90.21 \\
100 & $82.05 \pm 0.03$ & 87.07 \\
120 & $76.40 \pm 0.00$ & 76.90 \\
\hline
\end{tabular}

Berdasarkan tabel 1, diketahui bahwa kadar gliserol meningkat sesuai dengan peningkatan konsentrasi tawas dari $60 \mathrm{ppm}$ (83.14\%) sampai $80 \mathrm{ppm}(93.80 \%)$. Hal ini menunjukkan bahwa semakin besar konsentrasi tawas (koagulan) maka akan semakin banyak partikulat yang mampu diendapkan. Fenomena ini berbeda hasilnya ketika konsentrasi tawas dinaikkan menjadi 100 dan 120 ppm. Pada penambahan konsentrasi tawas sebesar 100 ppm dan 120 ppm, kadar gliserol mengalami penurunan secara berturut-turut menjadi $82.05 \%$ dan $76.40 \%$. Penurunan ini disebabkan restabilisasi koloid yaitu pecahnya endapan koloid jika konsentrasi koagulan yang ditambahkan berlebih dan mengakibatkan berkurangnya kadar gliserol dalam sampel (Rau dan Wooten, 1980). Oleh karena itu, konsentrasi tawas optimum pada proses adsorpsi dan koagulasi yaitu pada konsentrasi $80 \mathrm{ppm}$.

Setelah penentuan kadar gliserol, masing-masing hasil optimasi dari variasi konsentrasi tawas diuji penurunan intensitas warnanya menggunakan spektrofotometer UVVis. Berdasarkan tabel 1 dapat dilihat bahwa hasil optimum dari penurunan intensitas warna tertinggi diperoleh pada konsentrasi tawas $80 \mathrm{ppm}$. Pada kondisi konsentrasi optimum, yaitu konsentrasi $80 \mathrm{ppm}$ merupakan dosis koagulan yang sudah sesuai sehingga dapat mereduksi muatan listrik pada permukaan partikel-partikel koloid yang terdapat dalam crude glycerol akan melemah sehingga partikel akan bergabung membentuk makroflok. Kondisi ini telah mencapai kondisi konsentrasi yang optimum karena penambahan koagulan tawas tidak akan menimbulkan endapan. Hal ini ditunjukkan dengan peningkatan penurunan intensitas warna. Namun, penambahan dosis koagulan lebih lanjut tidak meningkatkan penurunan intensitas warna. Hal ini disebabkan dosis atau jumlah koagulan yang berlebih dapat menyebabkan terjadinya deflokulasi atau restabilisasi koloid karena adanya gaya tolak menolak antar muatan positif partikel sehingga penurunan intensitas warna semakin menurun karena flok-flok yang sudah terbentuk akan terpecah dan mengakibatkan kekeruhan kembali pada larutan crude glycerol (Rau dan Wooten, 1980).

\section{Pengaruh Variasi Waktu Adsorpsi dan Koagulasi}

Adsorpsi-koagulasi dilakukan dengan variabel tetap suhu $60{ }^{\circ} \mathrm{C}$, konsentrasi $\mathrm{H}$ zeolit $12 \%$ dari massa crude glycerol, ukuran tawas dan H-zeolit masing-masing $0.2 \mathrm{~mm}$, dan konsentrasi tawas optimum yang diperoleh pada tahap sebelumnya yaitu $80 \mathrm{ppm}$. Aalisis kadar gliserol hasil adsorpsikoagulasi dengan variasi suhu ditunjukkan pada tabel 2 .

Tabel 2. Kadar gliserol pada variasi waktu adsorpsi-koagulasi

\begin{tabular}{lll}
\hline $\begin{array}{l}\text { Waktu } \\
\text { (menit) }\end{array}$ & $\begin{array}{l}\text { Kadar Gliserol } \\
(\boldsymbol{\%})\end{array}$ & $\begin{array}{l}\text { Penurunan } \\
\text { Intensitas (\%) }\end{array}$ \\
\hline 30 & $86.26 \pm 0.03$ & 23.57 \\
60 & $89.88 \pm 0.00$ & 67.01 \\
75 & $93.80 \pm 0.03$ & 90.71 \\
90 & $83.99 \pm 0.00$ & 77.68 \\
\hline
\end{tabular}


Berdasarkan tabel 2 dapat dilihat bahwa waktu adsorpsi dan koagulasi optimum diperoleh pada menit ke-75. Kondisi optimum dilihat dari kadar gliserol yang diperoleh, dimana kadar gliserol mengalami peningkatan dari menit ke-30 hingga menit ke-75, namun mengalami penurunan pada menit ke-90. Pada waktu optimum (75 menit), kadar gliserol tertinggi (93.803\%) menunjukkan bahwa berkurangnya kadar senyawa pengotor seperti trigliserida, asam lemak bebas, metil ester, air, logam kalium dan aluminium yang telah terserap maksimal oleh adsorben teraktivasi yang digunakan. Selain berkurangnya senyawa pengotor, pada kondisi waktu optimum, proses koagulasi akan berlangsung cepat dalam pembentukan makroflok yang kemudian mengendap dan diserap oleh zeolit teraktivasi. Tetapi, pada menit ke-90, flok yang sudah terbentuk akan mengalami deflokulasi atau pecahnya flok-flok yang telah terbentuk (Winarni, 2003) dan mengakibatkan senyawa pengotor yang terdapat dalam crude glycerol akan terlepas kembali ke dalam larutan sampel.

Pada uji intensitas warna, dari hasil pengukuran nilai absorbansi yang diperoleh, untuk hasil optimum dari penurunan intensitas warna tertinggi diperoleh pada waktu 75 menit. Berdasarkan Tabel 2, penurunan intensitas warna mengalami peningkatan dari menit ke-30 sampai menit ke75 dan mengalami penurunan pada menit ke90. Hal ini disebabkan pada waktu optimum (75 menit), merupakan waktu yang sesuai untuk tawas dalam mereduksi muatan listrik pada permukaan partikel- partikel koloid yang terdapat dalam crude glycerol sehingga muatan listrik akan melemah yang menyebabkan partikel akan bergabung membentuk makroflok. Tetapi, peningkatan waktu koagulasi lebih lanjut tidak meningkatkan $\%$ penurunan intensitas warna melainkan mengalami penurunan dikarenakan flok-flok yang terbentuk akan terpecah dan mengakibatkan kekeruhan kembali pada crude glycerol (Risdianto, 2007).

\section{Pengaruh Variasi Suhu Adsorpsi dan Koagulasi}

Proses adsorpsi-koagulasi dilakukan dengan variabel tetap meliputi suhu $60{ }^{\circ} \mathrm{C}$, konsentrasi $\mathrm{H}$-zeolit $12 \%$ dari massa crude glycerol, ukuran tawas dan $\mathrm{H}$-zeolit masingmasing $0.2 \mathrm{~mm}$, dan konsentrasi tawas dan waktu adsorpsi-koagulasi optimum yang diperoleh pada tahap sebelumnya secara berturut-turut yaitu $80 \mathrm{ppm}$ dan 75 menit. Analisis kadar gliserol hasil adsorpsi dengan tawas dengan variasi suhu ditunjukkan pada Tabel 3.

Tabel 3. Kadar gliserol pada variasi suhu adsorpsikoagulasi

\begin{tabular}{lll}
\hline $\begin{array}{l}\text { Suhu } \\
\left({ }^{\circ} \mathbf{C}\right)\end{array}$ & $\begin{array}{l}\text { Kadar Gliserol } \\
(\boldsymbol{\%})\end{array}$ & $\begin{array}{l}\text { Penurunan } \\
\text { Intensitas }(\boldsymbol{\%})\end{array}$ \\
\hline 30 & $75.93 \pm 0.03$ & 76.86 \\
45 & $89.33 \pm 0.03$ & 84.09 \\
60 & $93.80 \pm 0.03$ & 90.40 \\
75 & $87.09 \pm 0.06$ & 51.82 \\
\hline
\end{tabular}

Berdasarkan tabel 3, dapat dilihat bahwa semakin tinggi suhu kadar gliserol yang dihasilkan semakin besar dan mencapai maksimum pada suhu $60{ }^{\circ} \mathrm{C}$ dengan kadar gliserol 93.80\%. Kenaikan suhu juga menyebabkan peningkatan adsorpsi, yaitu dapat meningkatkan energi kinetik dari senyawa pengotor yang terdapat dalam gliserol, sehingga senyawa pengotor ini mampu berdifusi lebih cepat ke dalam poripori adsorben (Hidayat et al., 2010). Peningkatan adsorpsi senyawa pengotor ini menunjukkan sifat endotermik adsorpsi, dimana zeolit akan meyerap panas dari lingkungan. Perlakuan pemanasan ini dapat menaikkan perbandingan $\mathrm{Si} / \mathrm{Al}$ sehingga proses adsorpsi menjadi lebih efektif dan dapat meningkatkan kadar gliserol (Aziz et al., 2014). Peningkatan suhu juga dapat meningkatkan kecepatan gerak partikel dalam sistem sehingga semakin banyak tumbukan antar partikel dalam sistem sehingga mempercepat terbentuknya flok. Kenaikan suhu akan meningkatkan kelarutan dari koagulan alum atau tawas, sehingga ion logam yang terdapat dalam crude glycerol lebih cepat ternetralisir membentuk flok seiring dengan kenaikan suhu.

Namun, saat suhu optimum telah tercapai, peningkatan suhu tidak lagi meningkatkan kadar gliserol yang diperoleh terbukti ketika suhu dinaikan menjadi $75{ }^{\circ} \mathrm{C}$ kadar gliserol turun menjadi $87.094 \%$. Hal ini disebabkan flok-flok yang sudah jenuh akan melarut kembali. Selain itu, pemanasan di atas suhu $60{ }^{\circ} \mathrm{C}$ dapat meningkatkan tekanan uap gliserol sehingga mengurangi kadar gliserol 
yang terdapat dalam sampel (The Soap and Detergent Association, 1990).

Berdasarkan hasil pengukuran nilai absorbansi yang diperoleh (tabel 3), untuk hasil optimum dari penurunan intensitas warna tertinggi diperoleh pada suhu $60^{\circ} \mathrm{C}$. Penurunan intensitas warna semakin meningkat dari suhu $30-60{ }^{\circ} \mathrm{C}$ dan menurun pada suhu $75{ }^{\circ} \mathrm{C}$. Semakin meningkatnya suhu, maka flok-flok yang terbentuk menjadi makroflok pun akan semakin cepat disebabkan karena adanya tumbukan antar partikel yang semakin banyak. Pada kenaikan suhu lebih lanjut, penurunan intensitas warna menurun. Hal ini disebabkan karena makroflok yang telah terbentuk akan larut kembali dalam larutan.

\section{Kualitas Gliserol Hasil Adsorpsi dan Koagulasi}

Kondisi optimum proses adsorpsi dan koagulasi yang diperoleh dengan menggunakan $\mathrm{H}$-zeolit sebanyak $12 \%$ dari massa sampel adalah konsentrasi tawas (koagulan) 80 ppm; waktu adsorpsi-koagulasi 75 menit; dan suhu adsorpsi-koagulasi $60{ }^{\circ} \mathrm{C}$. Berdasarkan kondisi optimum yang telah diperoleh, selanjutnya dilakukan analisis kualitas gliserol yang dihasilkan. Analisis kualitas gliserol hasil optimasi pemurnian crude glycerol menggunakan H-zeolit dan tawas disajikan pada tabel 4.

Berdasarkan tabel 4, dapat dilihat bahwa hasil optimasi pemurnian crude glycerol menggunakan $\mathrm{H}$-zeolit dan tawas secara keseluruhan lebih baik dan memenuhi syarat mutu gliserol kasar berdasarkan SNI 06-1564-1995 dibandingkan hasil analisis kualitas gliserol sebelum adsorpsi maupun setelah adsorpsi dengan H-zeolit. Kadar gliserol yang diperoleh pada kondisi optimum merupakan kadar gliserol yang tertinggi, yaitu 93.803\%. Hal ini menunjukkan bahwa $\mathrm{H}$-zeolit dan tawas yang digunakan berhasil mengurangi senyawa pengotor dalam crude glycerol seperti asam lemak bebas, metil ester, air dan kalium. Kadar air dan abu setelah adsorpsi mengalami penurunan dibandingkan dengan kadar air hasil crude glycerol setelah pengasaman masing-masing sebesar $7.250 \%$ dan $3.526 \%$. Sedangkan kadar MONG yang diperoleh pada hasil optimasi dengan $\mathrm{H}$-zeolit teraktivasi dan tawas $0.247 \%$.

Pada uji kualitatif adanya kandungan gula, dari ketiga proses yang dilakukan seluruhnya menunjukkan reaksi negatif. Hal ini ditunjukkan dari tidak terjadinya perubahan warna larutan crude glycerol menjadi warna coklat setelah ditambahkan pereaksi Maillard (gambar 1).

Tabel 4. Analisis kualitas gliserol

\begin{tabular}{clllll}
\hline No & Jenis Uji & $\begin{array}{l}\text { Sebelum } \\
\text { Adsorpsi }\end{array}$ & $\begin{array}{l}\text { Adsorpsi } \\
\text { dengan Zeolit }\end{array}$ & $\begin{array}{l}\text { Optimasi dengan } \\
\text { Zeolit dan Tawas }\end{array}$ & $\begin{array}{l}\text { SNI } \\
\mathbf{0 6 - 1 5 6 4 - 1 9 9 5}\end{array}$ \\
\hline 1. & Kadar Gliserol (\%) & $72.80 \pm 0.00$ & $77.08 \pm 0.03$ & $93.80 \pm 0.03$ & Min. $80 \%$ \\
2. & Kadar Air (\%) & $12.83 \pm 0.04$ & $10.76 \pm 0.02$ & $3.51 \pm 0.01$ & Maks. $10 \%$ \\
3. & Kadar Abu (\%) & $7.33 \pm 0.02$ & $5.96 \pm 0.01$ & $2.44 \pm 0.02$ & Maks. $10 \%$ \\
4. & Kadar MONG (\%) & $7.04 \pm 0.02$ & $6.20 \pm 0.08$ & $0.25 \pm 0.02$ & Maks. $2.5 \%$ \\
5. & Massa Jenis (g/mL) & $1.20 \pm 0.00$ & $1.38 \pm 0.00$ & $1.26 \pm 0.00$ & - \\
6. & Kadar Gula & - & - & - & - \\
7. & Kadar Logam K (ppm) & $3494.1 \mathrm{ppm}$ & $28281 \mathrm{ppm}$ & $2356.4 \mathrm{ppm}$ & - \\
8. & Kadar Logam Al & $518.4 \mathrm{ppm}$ & $431.7 \mathrm{ppm}$ & $410.7 \mathrm{ppm}$ & - \\
9. & Penurunan Intensitas & - & $87.696 \%$ & $90.395 \%$ & - \\
\hline
\end{tabular}




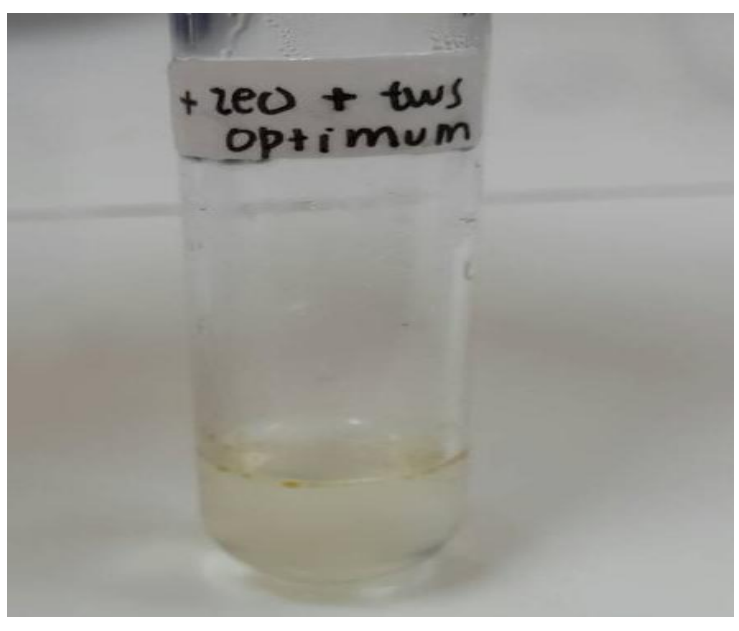

Gambar 1. Hasil uji kadar gula dalam crude glycerol pada kondisi optimum

Kadar logam kalium yang terdapat dalam gliserol hasil optimasi proses adsorpsi dan koagulasi diperoleh sebesar 2356 ppm (tabel 4). Hasil ini menunjukkan adanya penurunan kadar logam K. Molekul adsorbat dalam crude glycerol (garam mineral $\mathrm{K}_{3} \mathrm{PO}_{4}$ ) berada diantara molekul-molekul pengotor lainnya (asam lemak bebas, metil ester, sabun, dan air). Oleh karena itu, molekul adsorbat terlebih dahulu digumpalkan oleh koagulan (tawas) yang kemudian akan diendapkan oleh adsorben (Eckenfelder dan Wesley, 2000). Selanjutnya adsorbat berpindah atau menempel ke permukaan adsorben (zeolit), yang kemudian baru akan terserap pada permukaan zeolit. Kandungan logam kalium dalam crude glycerol mengalami proses pertukaran kation dengan $\mathrm{H}^{+}$yang terdapat dalam struktur zeolit (Hunsom et al., 2013).

Selain kadar logam kalium, hasil pengujian kadar logam aluminium $(\mathrm{Al})$ hasil optimasi dari proses adsorpsi dan koagulasi diperoleh sebesar $410 \mathrm{ppm}$, dimana hasil ini mengalami penurunan sebesar $26.224 \%$ dibandingkan dengan crude glycerol sebelum diadsorpsi dan koagulasi, dan kembali mengalami penurunan sebesar $4.865 \%$ jika dibandingkan dengan crude glycerol yang diadsorpsi dengan menggunakan $\mathrm{H}$-zeolit saja.

\section{SIMPULAN}

Berdasarkan hasil penelitian dapat disimpulkan bahwa kondisi optimum adsorpsi dan koagulasi menggunakan $\mathrm{H}$-zeolit dan tawas pada pemurnian crude glycerol diperoleh pada konsentrasi tawas 80 ppm, waktu 75 menit dan suhu $60{ }^{\circ} \mathrm{C}$. Kualitas gliserol yang diperoleh setelah proses adsorpsi dan koagulasi pada kondisi optimum memenuhi syarat mutu SNI 061564-1995 dengan kadar gliserol 93.803\%; kadar air $3.512 \%$; kadar abu $2.438 \%$; kadar MONG $0.247 \%$; tidak mengandung gula; penurunan intensitas warna sebesar $90.395 \%$; kadar logam kalium 2356 ppm dan aluminium $410 \mathrm{ppm}$.

\section{UCAPAN TERIMAKASIH}

Pada kesempatan ini penulis mengucapkan terimakasih kepada UIN Syarif Hidayatullah Jakarta khususnya Puslitpen UIN Syarif Hidayatullah Jakarta yang telah mendanai penelitian ini.

\section{DAFTAR PUSTAKA}

AOAC. 1995. Official Methods of Analysis of The Association of Analytical Chemists. Washington D.C.

Aziz I, Nurbayti S, Luthfiana F. 2010. Pemurnian gliserol dari hasil samping pembuatan biodiesel menggunakan bahan baku minyak goreng bekas. Valensi. 1: 157-162.

Aziz I, Las T, Shabrina A. 2014. Pemurnian crude glycerol dengan cara pengasaman dan adsorpsi menggunakan zeolit alam Lampung. Chem. Prog. 7: 66-73.

Hidayat Y, Rahardjo SB, Syarief. 2010. Optimasi kapasitas adsorpsi gliserol pada $\gamma-\mathrm{Al}_{2} \mathrm{O}_{3}$ dan efek tegangan permukaannya terhadap daya serap absorbansinya sebagai kajian awal pemisahan gliserol pada limbah biodiesel. Jurnal EkoSains. 2: 66-73.

Hunsom M, Autthanit C. 2013. Adsorptive purification of crude glycerol by sewage sludge derived activated carbon prepared by chemical activation with $\mathrm{H}_{3} \mathrm{PO}_{4}$, $\mathrm{K}_{2} \mathrm{CO}_{3}$, and $\mathrm{KOH}$. Chem. Eng. 229: 334343.

Kovaks A. 2011. Aspect of refining biodiesel by product glycerin. Journal of Petroleum and Coal. 1: 91-97.

Las T. 1989. Use Of Natural Zeolite For Nuclear Waste Treatment [Ph.D Tesis]. Manchester 
(UK): Department Chemistry and Applied Chemistry, Salford University.

Manosak R, Limpattayanate S, Hunsom M. 2010. Sequential-refining of crude glycerol derived from waste used-oil methyl ester plant via a combined process of chemical and adsorption. Fuel Process Technology. 104: 92-99.
Rau JG, Wooten DC. 1980. Environmental Impact Analysis Handbook. New York: Graw Hill Book Company.

SNI 06-1564-1995. Gliserol Kasar. Jakarta: Badan Standarisasi Nasional.

The Soap and Detergent Association. 1980. Glycerine: An Overview. New York. 